Relations industrielles

Industrial Relations

Are Seniority-Based Layoffs Discriminatory?

The Adverse Impact of Layoffs on Designated Groups

Les mises à pied basées sur l'ancienneté sont-elles discriminatoires?

Los despidos por antiguedad, son discriminatorios?

El impacto negativo de ciertos despidos por grupos designados

Gangaram Singh et Frank Reid

Volume 53, numéro 4, automne 1998

URI : https://id.erudit.org/iderudit/005299ar

DOI : https://doi.org/10.7202/005299ar

Aller au sommaire du numéro

Éditeur(s)

Département des relations industrielles de l'Université Laval

ISSN

0034-379X (imprimé)

1703-8138 (numérique)

Découvrir la revue

Citer cet article

Singh, G. \& Reid, F. (1998). Are Seniority-Based Layoffs Discriminatory? The Adverse Impact of Layoffs on Designated Groups. Relations industrielles /

Industrial Relations, 53(4), 730-749. https://doi.org/10.7202/005299ar

Tous droits réservés (C) Département des relations industrielles de l'Université Laval, 1998
Ce document est protégé par la loi sur le droit d'auteur. L'utilisation des services d'Érudit (y compris la reproduction) est assujettie à sa politique d'utilisation que vous pouvez consulter en ligne.

https://apropos.erudit.org/fr/usagers/politique-dutilisation/ 


\title{
Are Seniority-Based Layoffs Discriminatory?
}

\section{The Adverse Impact of Layoffs on Designated Groups ${ }^{1}$}

\author{
GANGARAM SINGH \\ Wheatherhead School of Management, Case Western Reserve University, \\ Cleveland, Ohio.
}

FRANK REID

Centre for Industrial Relations, University of Toronto, Toronto, Ontario.

The objectives of this paper are: first, to determine whether layoffs disproportionately affect members of employment equity designated groups; and, second, to assess the importance of seniority in any adverse impacts. Our hypothesis is that seniority is an important criterion for layoffs and that, on average, designated group members tend to have less seniority and would therefore be disproportionately affected by layoffs. If this hypothesis is correct, then layoffs may constitute systemic discrimination since there is a reasonable altemative policy in the form of reduced hours through worksharing, which would affect all groups similarly. Empirical tests confirmed that the probability of a layoff was higher for designated group members. The role of the senionity system in this relationship, however, was contrary to our hypothesis since the relationship between the probability of a layoff and designated group status was weaker at unionized workplaces than at nonunion workplaces. We conclude that the case for worksharing is strengthened by its potential to reduce the systemic discrimination against designated groups which results from the use of layoffs.

Although the "last-in-first-out" principle is associated with trade unions, workers were demanding the application of seniority in layoff

1. We would like to express our gratitude to John Kervin, participants of the $33^{\text {rd }}$ Annual Conference of the Canadian Industrial Relations Association, and participants of the Labor and Employment Systems Workshop in the Department of Labor and Human Resource Policy at Case Western Reserve University for helpful comments. 
decisions well before unions won the legitimate authority to bargain on behalf of workers. For example, the automobile industry conceded the demand for the application of seniority in layoffs in 1934 (Brody 1993); and the Great Depression heightened the demand for seniority when employers arbitrarily dismissed factory workers and both unions and workers saw the need for job security (Lapp 1946). Pro-labour legislation in the United States (the Wagner Act in 1935) and Canada (P.C. 1003 in 1944) resulted in large-scale collective bargaining, and one of the main demands of newly unionized factory workers was seniority (Lapp 1946). Today, the seniority-based layoff system has become a hallmark achievement for unions. According to data provided by the Workplace Information Directorate of Human Resource Development Canada (HRDC), in 1997, almost 70 percent of Canadian collective agreements contain a clause which mentions seniority as a criterion for the allocation of layoffs.

The seniority-based layoff system has also become a standard human resource management practice in nonunion workplaces. The widespread application of the system relates to the advantages it provides for all the actors of the employment relationship: it is easy to administer; it rewards the most experienced employees; it reduces the costly turnover of employees; it improves the morale of workers by assuring job security; and it reduces workers' concerns about the arbitrary behaviour of managers in the allocation of layoffs (Dulude 1995: 22). As such, Fischer (1976) concluded that the parties to the employment relationship had become accustomed to the seniority-based layoff system.

Because of its widespread application and perceived "fairness", the disadvantages of the "last-in-first-out" principle are given little emphasis. One such disadvantage became very controversial with the introduction of employment equity legislation in Canada and affirmative action legislation in the United States. The controversy surrounding the seniority-based layoff system centres on its potential to adversely affect members of the employment equity designated groups (women, visible minorities, persons with a disability, and people of aboriginal origins), in that these individuals are likely to be the most recent entrants to the labour market (Beatty 1983; U.S. Commission on Civil Rights 1977). As a result, the seniority-based layoff system could be a potential source of systemic discrimination, which in turn may frustrate any employment and promotional gains engendered by employment equity and affirmative action. ${ }^{2}$ It therefore seems that the seniority-based layoff system conflicts with the

2. We approach the concepts of employment equity and affirmative action from a broad perspective, involving the general notion of managing diversity. It is assumed that the implementation of "fair" hiring and promotional practices will result in a more productive workforce, which in turn will enhance the competitiveness of the organization. 
promotion of equality or progressive human resource management practices to encourage diversity in the workplace. Clearly, the relationship between layoffs and designated group status has several implications for both institutional and public policies.

This paper has the following two objectives. It first determines whether layoffs disproportionately affect members of the designated groups. It then assesses the importance of seniority in any adverse impacts. To our knowledge, this is the first systematic and direct study that uses national data to examine the adverse impacts of layoffs on employment equity designated groups. The next section examines the literature on layoffs. The third section outlines the conceptual issues which underlie the relationship between layoffs and designated group status. In the fourth section, we discuss our methodology, including a description of the data source, variables and a priori expectations, and data analysis techniques. The fifth section presents the results and the last section provides conclusions.

\section{LITERATURE REVIEW}

Layoffs result from a reduction in the demand for labour, which is in turn derived from the demand for goods and services. However, an employer can respond to a reduction in the demand for labour by reducing wages, reducing the number of employees through layoffs, or reducing the hours worked per employee through worksharing. One can argue that since unions have vigorously defended negotiated wages, by implication they must have endorsed layoffs (Weiss 1990).

The theoretical relationship between layoffs and unions has been investigated at three different levels. First, Medoff (1979) examined the association from a macro perspective, using the industry as the unit of analysis, and reported that industries with high unionization rates were more likely to have higher levels of layoffs than those with low unionization rates. Second, Montgomery (1991) also investigated the relationship from a macro perspective, but because he argued that the layoff decision is made by the firm (instead of the industry), he used data from 4,094 firms to show that the level of unionization was positively correlated with the level of layoffs. Third, Cornfield (1987) analysed the association between layoffs and union membership from a micro perspective, using the individual as the unit of analysis. Cornfield's main objective was to assess the effect of unionization on the determinants of ethnic inequality by investigating four groups of factors (ethnic, job, procedural, and individual characteristics). In order to achieve this objective, he estimated separate logit equations of layoffs for union members and nonunion 
members from an American telecommunications firm. He reported that, among the nonunion members, ethnic groups were more likely to be laid off than nonethnic groups.

Cornfield's results suggest that different criteria are used to allocate layoffs among union and nonunion members. Furthermore, the criteria used for nonunion members were having an adverse impact on ethnic groups. However, in an earlier study, Cornfield (1983) claimed that the layoff decision is made in two steps in both unionized and nonunionized workplaces. The initial decision, made by the employer, concerns which jobs are redundant. This usually follows a strategic human resource analysis of the jobs that are necessary for the core functions of the organization. The second stage involves an allocation of the remaining (nonredundant) jobs to an available pool of employees. Around the world, two general criteria are used to allocate layoffs - the impact of job loss on individuals and employees' qualifications (Yemen 1982). Over the years, family responsibility, seniority, and occupational qualifications have emerged as the major criteria to allocate layoffs (Yemen 1982). In conclusion, North America organizations frequently rely on seniority as a proxy for occupational qualifications (or expertise), and often use seniority as the most important criterion for the allocation of layoffs (Adell 1982).

\section{CONCEPTUAL ISSUES}

Our theory is based on the following assumptions. First, designated group employees are, on average, likely to have less seniority than white able-bodied males. Females are more likely to have less seniority than males because a woman's career is more likely to have been interrupted for child birth and child rearing than that of a man. Visible minorities are more likely to have spent less time in the labour force than whites because a higher proportion of visible minorities are likely to be recent immigrants to Canada. Persons with a disability are more likely than those without a disability to have interrupted their labour force attachment due to enrolment in a special training program or for medical reasons. ${ }^{3}$ Second, we assume that a significant number of employers use seniority as an important criterion in allocating layoffs. Last, we assume that the seniority principle is more systematically applied to unionized workers because of the frequency of seniority clauses in collective agreements.

3. The data do not contain information on people of aboriginal origin. Nevertheless, it should be noted that people of aboriginal origin are also more likely to be laid off since they have a shorter job tenure and interrupted labour force attachment. 
The implication is that designated group employees are, other things equal, more likely to be laid off than white able-bodied males. Thus, this system of seniority may constitute systemic discrimination, particularly since the availability of worksharing as an alternative to layoffs implies that there may not be bona fide business reasons for utilizing the layoff option. Furthermore, designated group employees may also be subject to direct discrimination in which employers with discretion in the layoff decision give preference to white able-bodied males. The worksharing option would also eliminate discrimination in such circumstances since under worksharing all the employees in the work group are treated similarly.

\section{Worksharing as an Alternative to Layoffs}

The Canadian worksharing program is administered by the federal government, and individuals receive unemployment insurance benefits for the time off due to worksharing. The program has received widespread support from employers, employees and local unions. Graves and Dugas (1993) reported that 88 percent of employers that participated in the program reported a high level of satisfaction with the policy. Not only do they get to keep their employees, the costs of worksharing are, on balance, less than the layoff alternative. Although worksharing may slightly increase the cost of fringe benefits, this is likely to be more than offset by savings from the cost inherent in hiring and training new employees at the end of the demand lapse. In addition, worksharing avoids the rise in average hourly labour cost when lower paid junior employees are laid off and higher paid senior employees are retained (Reid 1982, 1996).

There are also advantages for employees. Employees may take home over 90 percent of their weekly earnings and receive an additional day of leisure with worksharing. Many employees, even those who are not subject to layoff, will find this subsidized increase in leisure an attractive proposition. Furthermore, the advantages are greater for those who would have been laid off. Empirical evidence indicates that the majority of employees support worksharing, although a few employees have become accustomed to the full number of hours (Graves and Dugas 1993; Reid 1996; Fallon and Weiler 1984). However, this support for worksharing only applies when it is used as a temporary solution, and employees do not prefer the policy as a permanent work arrangement (Graves and Dugas 1993).

One would logically expect unions at all levels to support worksharing. However, national and local unions responded differently to the worksharing policy when it was introduced in Canada in 1982. The Canadian Labour Congress (CLC) opposed worksharing for two main reasons: (1) worksharing hides the real level of unemployment and prevents pol- 
icy makers from working towards the objective of full employment; and (2) worksharing can undermine seniority provisions by providing all employees with the same level of job security. This opposition is not diffused to the local organizations, which have tended to support worksharing (Reid 1982). The difference in opinion is probably due to the fact that national organizations have a more long-term vision, whereas local organizations respond to the immediate concerns of their members such as the devastating consequences of layoffs.

Worksharing also has advantages from a government or social perspective. Although it only redistributes the available work, leisure and unemployment insurance benefits, the distribution is critical. Reid (1982) argued that the improved distribution under worksharing is both more efficient and more equitable. It is clear that worksharing is not the only answer to unemployment. However, it is an effective part of the solution to unemployment. Finally, since surveys have shown that worksharing is supported by the general public, it is a politically attractive policy.

\section{METHODS}

\section{Data Source}

The data for this study are taken from the 1990 wave of the Statistics Canada Labour Market Activity Survey (LMAS). It contains information on a number of characteristics which are relevant to the layoff decision such as demographic characteristics, labour market participation, employment, work patterns, and job characteristics. Since the sample for the LMAS $(75,000)$ is taken from the Labour Force Survey, the population is considered to be representative of the civilian, non-institutionalized population, 16 to 69 years of age inclusive, who were residents of the ten provinces in January 1991.

Four groups were deleted from the sample since they were irrelevant to the study: (1) those who did not work at all in 1990 and therefore could have been experiencing permanent displacement; (2) those who had more than one job and therefore could have been laid off from one job and working in another; (3) those who had a part-time job, which may have been in the secondary labour market; and (4) those who were selfemployed and therefore could not be laid off. An additional 3,323 individuals were excluded because they reported an unemployment spell which was not due to a work interruption (e.g., a new entrant to the labour market) or they indicated a "non-layoff" reason for the work interruption (e.g., illness, accident, or pregnancy). The final sample consisted of 22,922 cases, comprised of 9,554 union and 13,368 nonunion full-time workers. 


\section{Variables and A Priori Expectations}

Dependent Variable: The dependent variable (LAYOFF) is defined as a dichotomous dummy variable coded one if the employee experienced a layoff during the year and zero otherwise. The definition of a layoff is that the employee experienced a work interruption due to a temporary layoff (seasonal or nonseasonal).

Independent Variables: The independent variables are described in Table 1. The primary independent variable is designated group status, defined to include women, visible minorities, and persons with a disability. We also conducted an alternative analysis in which separate dummy variables are used to represent women, visible minorities, and persons with a disability (hereinafter referred to as the disaggregate designated groups). Some respondents, of course, belonged to more than one of the disaggregate designated groups. Based on the theory outlined in the previous section, we expect that designated group members (both at the aggregate and disaggregate levels) are more likely to be laid off than white able-bodied males.

Control Variables: The relationship between layoffs and designated group status can be affected by various other factors, which can be categorized as other individual characteristics, job characteristics, and employer characteristics. Generally, older employees are less likely to be laid off than younger employees because age is positively related to job tenure and seniority. In addition, the older an employee, the more the firm is likely to have invested in firm-specific, human capital, making it more costly for an employer to lay off the employee. Teenaged employees may, however, also have a low layoff rate because their high voluntary turnover rate may reduce the need for an employer to utilize layoffs.

Education is part of an individual's human capital, and reflects ability, skills, qualifications, and expertise. It is hypothesized that employees with higher levels of education are less likely to be laid off than those with lower levels of education because the costs of hiring and training tend to rise with the skill level of the job.

Various job characteristics may affect the layoff decision. With regard to union status, there are conflicting tendencies. On the one hand, it is likely that, other things equal, a unionized employee is less likely to be laid off than a non-union employee because laying off an employee in a unionized environment involves the complications of the seniority system and the costs of the bumping procedure. On the other hand, the tendency of unions to resist wage reductions and reductions in hours would make layoffs more likely. 
TABLE 1

Definitions of Independent Variables

\begin{tabular}{|c|c|}
\hline Independent Variables & Definitions \\
\hline Designated groups & $\begin{array}{l}\text { Dummy equal to } 1 \text { if employee was a female, a visible minority, or a } \\
\text { person with a disability }\end{array}$ \\
\hline Female & Dummy equal to 1 if employee was a female \\
\hline Visible minority & Dummy equal to 1 if employee was a visible minority \\
\hline Person with a disability & Dummy equal to 1 if employee was a person with a disability \\
\hline $\begin{array}{l}\text { Age [Below } 20 \text { and } \\
\text { above } 64]\end{array}$ & $\begin{array}{l}\text { Dummy equal to } 1 \text { if employee was below } 20 \text { years old or above } 64 \\
\text { years old }\end{array}$ \\
\hline $20-24$ & Dummy equal to 1 if employee was between 20 and 24 years old \\
\hline $25-34$ & Dummy equal to 1 if employee was between 25 and 34 years old \\
\hline $35-44$ & Dummy equal to 1 if employee was between 35 and 44 years old \\
\hline $45-54$ & Dummy equal to 1 if employee was between 45 and 54 years old \\
\hline $55-64$ & Dummy equal to 1 if employee was between 55 and 64 years old \\
\hline Married & Dummy equal to 1 if employee was married \\
\hline $\begin{array}{l}\text { Education [Below high } \\
\text { school] }\end{array}$ & $\begin{array}{l}\text { Dummy equal to } 1 \text { if employee had } 0-8 \text { years of schooling, } \\
\text { including some high school education }\end{array}$ \\
\hline High school & Dummy equal to 1 if employee graduated from high school \\
\hline Above high school & $\begin{array}{l}\text { Dummy equal } 1 \text { if employee had some post-secondary, post- } \\
\text { secondary, or some university education }\end{array}$ \\
\hline Vocational training & Dummy equal to 1 if employee had a trade certificate or a diploma \\
\hline Union member & Dummy equal to 1 if employee was a union member \\
\hline White-collar sector & $\begin{array}{l}\text { Dummy equal } 1 \text { if employee belonged to Statistics Canada codes } \\
\text { SOC1 01-28 }\end{array}$ \\
\hline Hourly paid & Dummy equal to 1 if employee was paid on a hourly basis \\
\hline $\begin{array}{l}\text { Industry [Natural } \\
\text { Resources] }\end{array}$ & $\begin{array}{l}\text { Dummy equal to } 1 \text { if employee belonged to Statistics Canada codes } \\
\text { SIC1 01-08 }\end{array}$ \\
\hline Manufacturing & $\begin{array}{l}\text { Dummy equal to } 1 \text { if employee belonged to Statistics Canada codes } \\
\text { SIC1 09-28 }\end{array}$ \\
\hline Construction & $\begin{array}{l}\text { Dummy equal to } 1 \text { if employee belonged to Statistics Canada codes } \\
\text { SIC1 } 29-30\end{array}$ \\
\hline Transportation & $\begin{array}{l}\text { Dummy equal to } 1 \text { if employee belonged to Statistics Canada codes } \\
\text { SIC1 31-34 }\end{array}$ \\
\hline Trade & $\begin{array}{l}\text { Dummy equal to } 1 \text { if employee belonged to Statistics Canada codes } \\
\text { SIC1 35-36 }\end{array}$ \\
\hline Finance & $\begin{array}{l}\text { Dummy equal to } 1 \text { if employee belonged to Statistics Canada codes } \\
\text { SIC1 } 37-39\end{array}$ \\
\hline Services & $\begin{array}{l}\text { Dummy equal to } 1 \text { if employee belonged to Statistics Canada codes } \\
\text { SIC1 } 40-47 \text { and } 52\end{array}$ \\
\hline Public Administration & $\begin{array}{l}\text { Dummy equal to } 1 \text { if employee belonged to Statistics Canada codes } \\
\text { SIC1 48-51 }\end{array}$ \\
\hline Region [East] & $\begin{array}{l}\text { Dummy equal to } 1 \text { if employee belonged to Newfoundland, Prince } \\
\text { Edward Island, Nova Scotia, or New Brunswick }\end{array}$ \\
\hline
\end{tabular}


TABLE 1

Definitions of Independent Variables (continued)

\begin{tabular}{|c|c|}
\hline Independent Variables & Definitions \\
\hline Central & Dummy equal to 1 if employee belonged to Quebec or Ontario \\
\hline Prairies & $\begin{array}{l}\text { Dummy equal to } 1 \text { if employee belonged to Manitoba, } \\
\text { Saskatchewan, or Alberta }\end{array}$ \\
\hline British Columbia & Dummy equal to 1 if employee belonged to British Columbia \\
\hline Employer size [Small] & $\begin{array}{l}\text { Dummy equal to } 1 \text { if employee's employer had below } 100 \\
\text { employees }\end{array}$ \\
\hline Medium & $\begin{array}{l}\text { Dummy equal to } 1 \text { if employee's employer had between } 100 \text { and } \\
499 \text { employees }\end{array}$ \\
\hline Large & $\begin{array}{l}\text { Dummy equal to } 1 \text { if employee's employer had more than } 500 \\
\text { employees }\end{array}$ \\
\hline Unknown & $\begin{array}{l}\text { Dummy equal to } 1 \text { if number of employee at employee's employer } \\
\text { was unknown }\end{array}$ \\
\hline
\end{tabular}

Note: square brackets indicate reference categories for subsequent statistical analyses.

It is possible that certain jobs are more stable than other ones. In this regard, white-collar jobs are hypothesized to be more stable than blue-collar jobs. Therefore, white-collar job incumbents are less likely to be laid off than blue-collar workers. Similarly, hourly paid jobs can be thought of as being unstable, leading to the prediction that hourly paid job incumbents are more likely to be laid off than salaried employees.

The final set of characteristics which may affect an individual's layoff chances relates to the employer. Individuals who work in the service sector (e.g., finance and public administration) are less likely to be laid off than those who work in the goods sector (e.g., manufacturing and construction), since the goods sector experiences greater cyclical fluctuation.

With regard to firm size, those who work for large firms are less likely to be laid off than those who work for small organizations as a result of several factors. A large firm is likely to have a greater share of the product market, making it less vulnerable to demand shifts between firms. A large firm is also more likely to have a diversified line of products, making it less vulnerable to a reduction in demand for any one of its product lines. Finally, large firms are more likely than small ones to carry an inventory of labour (i.e., a buffer) in economic downturns.

We have no hypothesis regarding the independent effect of region but regional dummies are included as control variables. They may capture differences in industry composition that are not captured by our broad industry dummies. 


\section{Data Analysis Techniques}

The data is analysed in a number of stages. The initial step involves a comparison of the unadjusted layoff rates for designated groups to the comparison group of white able-bodied males. The impact of two key variables, union status and industry mix, are then examined in a bivariate context. Finally, a multivariate logistic regression analysis is used to control for the impact of numerous individual, job and employer characteristics. The latter analysis also includes separate assessments for the aggregate and disaggregate designated groups.

\section{RESULTS}

Table 2 shows that, for the overall sample, 4.07 percent of the respondents experienced an unemployment spell due to temporary layoffs. Means (and standard deviations) of the independent variables are presented in Table 3. With regard to the key variables of interest, 49 percent of the sample are designated group members and 42 percent of the sample are members of a union.

The first column of Table 2 shows that the layoff rate for designated group members is 3.28 percent, a lower level than the 4.85 percent layoff rate for white able-bodied males. Among the disaggregate designated groups, the layoff rate is lower for females (2.98 percent) than for males (4.86 percent), and it is lower for visible minorities (3.19 percent) than for white individuals ( 4.11 percent). Only persons with a disability, a relatively small group, experienced a higher level of layoffs ( 4.90 percent) than their able-bodied counterparts (4.00 percent). Overall, the unadjusted layoff rates do not reveal any tendency for designated group members to be disproportionately affected by layoffs.

We next examine layoff rates separately in the union and nonunion sectors to investigate the hypothesis that union status may heighten any adverse effect on designated group members, based on the assumptions that designated group members have less seniority and that seniority may play a relatively greater role in determining layoffs in the union sector than the nonunion sector. The data in the last two columns of Table 2 do not support this hypothesis. In fact, the layoff rate of designated group members is lower in both the union and the nonunion sectors, and the designated group advantage is greater in the union sector.

The next hypothesis we investigated is that the relatively low rate of layoff of designated group members may simply reflect the industry mix. That is, designated group members may be disproportionately employed in industries that have low layoff rates. Table 4 presents the layoff rates and 
TABLE 2

Layoff Rates (in percent) for Designated Groups by Union Membership

\begin{tabular}{lccc}
\hline & & \multicolumn{2}{c}{ Layoff Rates by Union Membership (II) } \\
\cline { 3 - 4 } \multicolumn{1}{c}{ Designated Groups } & $\begin{array}{c}\text { Layoff Rates for the Full } \\
\text { Sample }(I)\end{array}$ & $\begin{array}{c}\text { Nonunion } \\
\text { Members }\end{array}$ & Union Members \\
\hline White able-bodied males & 4.85 & 4.23 & 5.64 \\
Designated groups & 3.28 & 3.15 & 3.47 \\
Males & 4.86 & 4.20 & 5.69 \\
Females & 2.98 & 3.02 & 2.93 \\
Whites & 4.11 & 3.75 & 4.62 \\
Visible minorities & 3.19 & 2.17 & 4.94 \\
Able-bodied persons & 4.00 & 3.61 & 4.55 \\
Persons with a disability & 4.90 & 4.50 & 5.38 \\
Mean layoff rates & 4.07 & 3.68 & 4.63 \\
Number of observations & 22,922 & 13,368 & 9,554 \\
\hline
\end{tabular}

employment shares by industry for both members of the designated groups and white able-bodied males. The data in Table 4 show that designated group members have relatively low employment shares in the three industry groups which have above-average layoff rates (natural resources, manufacturing and construction). Conversely, designated group members are disproportionately employed in industries such as finance and services which have below-average layoff rates.

In order to investigate the impact of industry mix, we derive the hypothetical layoff rate that designated group members would have if they had the industry employment shares of white able-bodied males. This is accomplished by calculating a hypothetical weighted average layoff rate using the actual designated group layoff rate for each industry, weighted by the white able-bodied employment share for each industry. In Table 4 , this hypothetical layoff rate is shown to be 4.80 percent. Therefore, if the industry distribution of designated group employees was identical to that of white able-bodied males, then their hypothetical layoff rate (4.80 percent) would be almost equal to that of white able-bodied males ( 4.85 percent). This demonstrates that the relatively low aggregate layoff rate of designated group members is due to the mix of industries in which they are employed.

We now turn to the multivariate logistic regression results presented in Table 5. The dependent variable is the dichotomous variable LAYOFF and the independent variables are the set of individual, job, and employer characteristics previously discussed. The key result is that the coefficient of the designated group variable is positive and statistically significant (at the 10 percent significance level). This suggests that, controlling for other 
TABLE 3

Means and Standard Deviations (in parentheses) for the Independent Variables by Layoff Status

\begin{tabular}{|c|c|c|c|}
\hline \multirow[b]{2}{*}{ Independent Variables } & \multirow[b]{2}{*}{ Means for the Full Sample (I) } & \multicolumn{2}{|c|}{ Layoff Status (II) } \\
\hline & & Employed & Laid off \\
\hline Designated groups & $0.49(0.50)$ & $0.50(0.50)$ & $0.39(0.49)$ \\
\hline Female & $0.42(0.49)$ & $0.42(0.50)$ & $0.31(0.46)$ \\
\hline Visible minority & $0.04(0.19)$ & $0.04(0.19)$ & $0.03(0.17)$ \\
\hline Person with a disability & $0.09(0.28)$ & $0.09(0.29)$ & $0.10(0.31)$ \\
\hline $\begin{array}{l}\text { Age [Below } 20 \text { and } \\
\text { above } 64 \text { ] }\end{array}$ & $0.04(0.19)$ & $0.04(0.20)$ & $0.03(0.19)$ \\
\hline $20-24$ & $0.09(0.29)$ & $0.09(0.29)$ & $0.10(0.31)$ \\
\hline $25-34$ & $0.29(0.46)$ & $0.29(0.45)$ & $0.32(0.47)$ \\
\hline $35-44$ & $0.30(0.46)$ & $0.30(0.46)$ & $0.29(0.46)$ \\
\hline $45-54$ & $0.19(0.39)$ & $0.19(0.39)$ & $0.17(0.37)$ \\
\hline $55-64$ & $0.09(0.29)$ & $0.09(0.29)$ & $0.09(0.28)$ \\
\hline Married & $0.72(0.45)$ & $0.72(0.45)$ & $0.74(0.50)$ \\
\hline $\begin{array}{l}\text { Education [Below high } \\
\text { school] }\end{array}$ & $0.26(0.44)$ & $0.25(0.43)$ & $0.48(0.50)$ \\
\hline High school & $0.24(0.43)$ & $0.24(0.43)$ & $0.22(0.42)$ \\
\hline Above high school & $0.42(0.49)$ & $0.43(0.49)$ & $0.20(0.40)$ \\
\hline Vocational training & $0.08(0.28)$ & $0.08(0.28)$ & $0.10(0.30)$ \\
\hline Union member & $0.42(0.49)$ & $0.41(0.49)$ & $0.47(0.50)$ \\
\hline White-collar sector & $0.66(0.47)$ & $0.68(0.47)$ & $0.26(0.44)$ \\
\hline Hourly paid & $0.57(0.49)$ & $0.56(0.50)$ & $0.84(0.37)$ \\
\hline $\begin{array}{l}\text { Industry [Natural } \\
\text { Resources] }\end{array}$ & $0.06(0.24)$ & $0.06(0.24)$ & $0.13(0.34)$ \\
\hline Manufacturing & $0.19(0.39)$ & $0.18(0.38)$ & $0.38(0.49)$ \\
\hline Construction & $0.05(0.22)$ & $0.05(0.21)$ & $0.14(0.35)$ \\
\hline Transportation & $0.10(0.29)$ & $0.10(0.30)$ & $0.07(0.25)$ \\
\hline Trade & $0.15(0.36)$ & $0.15(0.36)$ & $0.05(0.22)$ \\
\hline Finance & $0.05(0.22)$ & $0.05(0.22)$ & $0.01(0.08)$ \\
\hline Services & $0.30(0.46)$ & $0.31(0.46)$ & $0.17(0.39)$ \\
\hline Public Administration & $0.10(0.30)$ & $0.10(0.30)$ & $0.05(0.21)$ \\
\hline Region [East] & $0.25(0.43)$ & $0.24(0.43)$ & $0.37(0.48)$ \\
\hline Central & $0.36(0.48)$ & $0.38(0.48)$ & $0.36(0.48)$ \\
\hline Prairies & $0.28(0.45)$ & $0.29(0.45)$ & $0.16(0.37)$ \\
\hline British Columbia & $0.10(0.30)$ & $0.10(0.30)$ & $0.11(0.31)$ \\
\hline Employer size [Small] & $0.38(0.48)$ & $0.35(0.48)$ & $0.40(0.49)$ \\
\hline Medium & $0.13(0.34)$ & $0.13(0.33)$ & $0.13(0.33)$ \\
\hline Large & $0.38(0.49)$ & $0.39(0.49)$ & $0.31(0.46)$ \\
\hline Unknown & $0.14(0.34)$ & $0.14(0.34)$ & $0.16(0.37)$ \\
\hline Number of observations & 22,922 & 21,988 & 934 \\
\hline
\end{tabular}

Note: square brackets indicate the reference categories for subsequent statistical analyses. 
TABLE 4

Assessing the Impact of Employment Shares (Aggregation Weights) on the Layoff Rate of Designated Group Members

\begin{tabular}{lcccc}
\hline \multirow{2}{*}{ Industry } & \multicolumn{2}{c}{ Designated Groups } & \multicolumn{2}{c}{ White Able-Bodied Males } \\
\cline { 2 - 5 } & Layoff Rates & $\begin{array}{c}\text { Employment } \\
\text { Shares } \\
\left(L R_{i}^{d}\right)\end{array}$ & $\begin{array}{c}\text { Layoff Rates } \\
\left(k_{i}^{d}\right)\end{array}$ & $\begin{array}{c}\text { Employment } \\
\text { Shares }\end{array}$ \\
\hline Natural Resources & 8.01 & 3.6 & 9.07 & $\left(k_{i}^{w}\right)$ \\
Manufacturing & 9.73 & 13.6 & 7.51 & 8.8 \\
Construction & 9.87 & 2.1 & 11.95 & 7.8 \\
Transportation & 1.31 & 6.1 & 3.64 & 13.0 \\
Trade & 1.25 & 14.8 & 1.46 & 15.3 \\
Finance & 0.61 & 7.3 & 0.30 & 2.8 \\
Services & 2.26 & 43.1 & 2.47 & 18.1 \\
Public & 1.88 & 9.4 & 1.87 & 10.6 \\
Administration & 3.28 & 100 & 4.85 & 100 \\
\hline All Industries & $\sum L R_{i}^{d} k_{i}^{w}=4.80$ & & \\
\hline Hypothetical layoff rate $=$ &
\end{tabular}

Note: Employment shares may not add up to 100 because of rounding.

factors (such as age, education, and industry mix), designated group members have a higher probability of being laid off than white able-bodied males. This supports the hypothesis that layoffs adversely affect designated groups, and as such may constitute a form of systemic discrimination against such groups.

The pattern of coefficients for the other independent variables in the logistic regression analysis is broadly as expected. The probability of a layoff tends to decline with both age and with level of education. White-collar employees were less likely to be laid off, while hourly paid employees were more likely to be laid off. Employees in service industries, such as trade and finance, were less likely to be laid off than employees in the natural resources sector. In addition, workers who were employed by a large organization were less likely to be laid off than those employed by a small organization. Finally, the results of this analysis indicate that union status has no significant impact on the probability of a layoff.

Table 6 presents the results of a logistic regression in which the single designated group variable is replaced by the three disaggregate designated group variables. Only the female variable has a positive and significant coefficient. The visible minorities variable and the persons with a disability variable are not significant, and the coefficient of the former is negative. This indicates that the finding of a higher layoff rate for desig- 
TABLE 5

\section{Layoff Logit Estimates by Union Membership (standard error in parentheses)}

\begin{tabular}{|c|c|c|c|}
\hline Independent Variables & $\begin{array}{c}\text { Logit Coefficients } \\
\text { (Full Sample) }\end{array}$ & $\begin{array}{l}\text { Logit Coefficients } \\
\text { (Nonunion } \\
\text { Members) }\end{array}$ & $\begin{array}{l}\text { Logit Coefficients } \\
\text { (Union Members) }\end{array}$ \\
\hline Designated groups & $0.14(.078)^{*}$ & $0.19(0.11)$ & $-0.10(0.11)$ \\
\hline \multicolumn{4}{|l|}{$\begin{array}{l}\text { Age [Below } 20 \text { and above } \\
64 \text { ] }\end{array}$} \\
\hline $\begin{array}{l}20-24 \\
25-34 \\
35-44 \\
45-54 \\
55-64\end{array}$ & $\begin{array}{l}1.24(.262) * * * \\
1.31(.253)^{* * *} \\
1.21(.257) * * * \\
1.01(.263) * * * \\
0.90(.273)^{* * *}\end{array}$ & $\begin{array}{l}1.05(0.29) * * * \\
1.27(0.28) * * * \\
1.24(0.29) * * * \\
0.96(0.30) * * * \\
0.97(0.32) * * *\end{array}$ & $\begin{array}{l}1.67(0.75)^{* *} \\
1.44(0.73)^{* *} \\
1.28(0.74)^{*} \\
1.17(0.74) \\
0.97(0.75)\end{array}$ \\
\hline Married & $0.02(.088)$ & $0.19(0.12)$ & $-0.17(0.13)$ \\
\hline $\begin{array}{l}\text { Education [Below high } \\
\text { school] } \\
\text { High school } \\
\text { Above high school } \\
\text { Vocational training }\end{array}$ & $\begin{array}{l}-0.36(.092)^{* * *} \\
-0.73(.100)^{* * *} \\
-0.35(.123)^{* * *}\end{array}$ & $\begin{array}{l}-0.25(0.12)^{* *} \\
-0.84(0.14)^{* * *} \\
-0.30(0.17)^{*}\end{array}$ & $\begin{array}{l}-0.46(0.14)^{* * *} \\
-0.53(0.14)^{* * *} \\
-0.36(0.18)^{* * *}\end{array}$ \\
\hline Union member & $-0.03(.082)$ & N/A & N/A \\
\hline White-collar sector & $-1.13(.112)^{* * *}$ & $-1.21(0.14)^{* * *}$ & $-0.93(0.18)^{* * *}$ \\
\hline Hourly paid & $0.78(.098)^{* * *}$ & $0.78(0.12) * * *$ & $0.84(0.19) * * *$ \\
\hline $\begin{array}{l}\text { Industry [Natural Resource } \\
\text { Manufacturing } \\
\text { Construction } \\
\text { Transportation } \\
\text { Trade } \\
\text { Finance } \\
\text { Services } \\
\text { Public Administration }\end{array}$ & $\begin{array}{c}-0.27(.116)^{* *} \\
-0.03(.141) \\
-1.10(.163)^{* * *} \\
-1.60(.184)^{* * *} \\
-1.67(.431)^{* * *} \\
-0.50(.152)^{* * *} \\
-0.85(.193)^{* * *}\end{array}$ & $\begin{array}{c}-0.70(0.16)^{* * *} \\
-0.23(0.16) \\
-0.71(0.22)^{* * *} \\
-1.77(0.21)^{* * *} \\
-1.67(0.48)^{* * *} \\
-0.53(0.19)^{* * *} \\
-0.35(0.27)\end{array}$ & $\begin{array}{c}0.14(0.18) \\
0.34(0.24) \\
-1.14(0.25)^{* * *} \\
-1.29(0.40)^{* * *} \\
-1.57(1.03) \\
-0.52(0.26)^{* *} \\
-1.02(0.29)^{* * *}\end{array}$ \\
\hline $\begin{array}{l}\text { Region [East] } \\
\text { Central } \\
\text { Prairies } \\
\text { British Columbia }\end{array}$ & $\begin{array}{l}-0.44(.083)^{* * *} \\
-0.88(.103)^{* * *} \\
-0.28(.122)^{* *}\end{array}$ & $\begin{array}{l}-0.57(0.12)^{* * *} \\
-0.89(0.13)^{* * *} \\
-0.50(0.19)^{* * *}\end{array}$ & $\begin{array}{l}-0.30(0.12)^{* * *} \\
-0.95(0.18)^{* * *} \\
-0.09(0.16)\end{array}$ \\
\hline $\begin{array}{l}\text { Employer size [Small] } \\
\text { Medium } \\
\text { Large } \\
\text { Unknown }\end{array}$ & $\begin{array}{c}-0.13(.118) \\
-0.24(.096)^{* * *} \\
0.17(.107)\end{array}$ & $\begin{array}{c}0.01(0.16) \\
-0.54(0.15)^{* * *} \\
-0.02(0.14)\end{array}$ & $\begin{array}{c}-0.01(0.19) \\
0.09(0.16) \\
0.56(0.18)^{* * *}\end{array}$ \\
\hline Constant & $-3.05(.265)^{* * *}$ & $-2.88(0.29) * * *$ & $-3.71(0.78)^{* * *}$ \\
\hline Model chi-square (d.f.) & $1163.14(26)$ & $694.09(25)$ & $553.60(25)$ \\
\hline Number of observations & 22,922 & 13,368 & 9,554 \\
\hline
\end{tabular}

Note: ${ }^{*}=$ significant at $10 \%,{ }^{*}=$ significant at $5 \%$, and ${ }^{* *}=$ significant at $1 \%$. 
nated group members in the previous aggregate equation was due entirely to a higher layoff rate for females.

The final analysis which we undertake is to investigate the impact of union membership on the layoff probability of designated group members by conducting separate analyses for the union and nonunion sectors. The results, presented in the third column of Table 5 , indicate that the positive and significant coefficient on the designated group variable does not occur in the union sector. In the union sector, the designated group variable is insignificant (and in fact has a negative sign). In the union regression containing the three disaggregate designated group variables, the coefficients of females, visible minorities and persons with a disability are all insignificant (Table 6).

In Table 6, the logistic regression equation for the nonunion sector reveal that the positive coefficient for designated groups in the aggregate equation (Table 5) resulted exclusively from a significant positive coefficient for females in the nonunion sector. The coefficients of the visible minorities variable and the persons with a disability variable are both insignificant.

In summary, the unadjusted aggregate data showed that the gross layoff rate for designated group members was actually lower than the gross layoff rate for white able-bodied males. A simple standardization analysis, however, revealed that this difference primarily reflected the impact of the industry mix - designated group members are employed disproportionately in industries with below-average layoff rates. The multivariate logistic regression analysis revealed that designated group members have a higher layoff rate than white able-bodied males, after controlling for a wide range of other factors. Separate regression equations for the union and nonunion sectors, including disaggregate designated group variables, indicated that the high layoff rate of designated group members results exclusively from a high layoff probability for females in the nonunion sector. In the union sector, there is no impact of designated group status on the probability of a layoff.

\section{CONCLUSIONS}

The first conclusion is that there is some support for the hypothesis that designated group members are disproportionately affected by layoffs, although this is limited to females in the nonunion sector. In addition, there is very little support for the assumption that the seniority-based layoff system in the union sector is responsible for systemic discrimination against members of the designated groups. In fact, employment in the 
TABLE 6

Layoff Logit Estimates for Females, Visible Minorities, and Persons with a Disability by Union Membership (standard error in parentheses)

\begin{tabular}{|c|c|c|c|}
\hline Designated Groups & $\begin{array}{l}\text { Logit Coefficients } \\
\text { (Full Sample) }\end{array}$ & $\begin{array}{c}\text { Logit Coeffieients } \\
\text { (Nonunion Members) }\end{array}$ & $\begin{array}{l}\text { Logit Coefficients } \\
\text { (Union Members) }\end{array}$ \\
\hline Females & $0.27(0.09) * * *$ & $0.32(0.12) * * *$ & $0.19(0.14)$ \\
\hline Visible minorities & $-0.20(0.20)$ & $-0.46(0.30)$ & $0.20(0.28)$ \\
\hline Persons with a disability & $0.03(0.11)$ & $0.06(0.16)$ & $-0.002(0.16)$ \\
\hline $\begin{array}{l}\text { Age [Below } 20 \text { and above } \\
20-24 \\
25-34 \\
35-44 \\
45-54 \\
55-64\end{array}$ & $\begin{array}{l}1.24(0.26)^{* * *} \\
0.32(0.25)^{* * *} \\
0.22(0.26)^{* * *} \\
1.02(0.26)^{* * *} \\
0.92(0.27)^{* * *}\end{array}$ & $\begin{array}{l}1.06(0.29)^{* * *} \\
1.28(0.29)^{* * *} \\
1.25(0.29)^{* * *} \\
0.97(0.30)^{* * *} \\
1.00(0.12)^{* * *}\end{array}$ & $\begin{array}{l}1.67(0.75)^{* *} \\
1.44(0.73)^{* *} \\
1.28(0.74)^{*} \\
1.18(0.74) \\
0.98(0.75)\end{array}$ \\
\hline Married & $0.01(0.09)$ & $0.18(0.12)$ & $-0.17(0.13)$ \\
\hline $\begin{array}{l}\text { Education [Below high schn } \\
\text { High school } \\
\text { Above high school } \\
\text { Vocational training }\end{array}$ & $\begin{array}{l}-0.36(0.09)^{* * *} \\
-0.73(0.10)^{* * *} \\
-0.36(0.12)^{* * *}\end{array}$ & $\begin{array}{l}-0.25(0.12)^{* *} \\
-0.83(0.14)^{* * *} \\
-0.29(0.17)^{*}\end{array}$ & $\begin{array}{l}-0.47(0.14)^{* * *} \\
-0.53(0.14)^{* * *} \\
-0.35(0.18)^{* *}\end{array}$ \\
\hline Union member & $-0.03(0.08)$ & N/A & N/A \\
\hline White-collar sector & $-1.19(0.12)^{* * *}$ & $-1.28(0.15)^{* * *}$ & $-0.97(0.19) * * *$ \\
\hline Hourly paid & $0.76(1.10)^{* * *}$ & $0.78(0.12)^{* * *}$ & $0.83(0.19) * * *$ \\
\hline $\begin{array}{l}\text { Industry [Natural Resour } \\
\text { Manufacturing } \\
\text { Construction } \\
\text { Transportation } \\
\text { Trade } \\
\text { Finance } \\
\text { Services } \\
\text { Public Administration }\end{array}$ & $\begin{array}{l}-0.27(0.12)^{* *} \\
-0.02(0.14) \\
-1.00(0.16)^{* * *} \\
-1.60(0.18)^{* * *} \\
-1.69(0.43)^{* * *} \\
-0.52(0.15)^{* * *} \\
-0.85(0.19)^{* * *}\end{array}$ & $\begin{array}{c}-0.68(0.16)^{* * *} \\
-0.20(0.18) \\
-0.68(0.22)^{* * *} \\
-1.75(0.21)^{* * *} \\
-1.69(0.48)^{* * *} \\
-0.53(0.19)^{* * *} \\
-0.33(0.27)\end{array}$ & $\begin{array}{c}0.12(0.19) \\
0.34(0.24) \\
-1.15(0.25)^{* * *} \\
-1.31(0.40)^{* * *} \\
-1.60(1.03) \\
-0.56(0.26)^{* *} \\
-1.03(0.28)^{* * *}\end{array}$ \\
\hline $\begin{array}{l}\text { Region [East] } \\
\text { Central } \\
\text { Prairies } \\
\text { British Columbia }\end{array}$ & $\begin{array}{l}-0.43(0.08)^{* * *} \\
-0.86(0.10)^{* * *} \\
-0.26(0.12)^{* *}\end{array}$ & $\begin{array}{l}-0.55(0.12)^{* * *} \\
-0.83(0.13)^{* * *} \\
-0.47(0.19)^{* * *}\end{array}$ & $\begin{array}{l}-0.30(0.12)^{* * *} \\
-0.96(0.18)^{* * *} \\
-0.09(0.17)\end{array}$ \\
\hline $\begin{array}{l}\text { Employer size [Small] } \\
\text { Medium } \\
\text { Large } \\
\text { Unknown }\end{array}$ & $\begin{array}{c}-0.13(0.12) \\
-0.23(1.10)^{* *} \\
0.17(0.11)\end{array}$ & $\begin{array}{c}0.01(0.16) \\
-0.53(0.15)^{* * *} \\
-0.01(0.14)\end{array}$ & $\begin{array}{c}-0.01(0.19) \\
0.09(0.16) \\
0.57(0.18)^{* * *}\end{array}$ \\
\hline Constant & $-3.07(0.26)^{* * *}$ & $-2.92(0.29) * * *$ & $-3.70(0.78)^{* * *}$ \\
\hline $\begin{array}{l}\text { Model chi-square (d.f.) } \\
\text { Number of observations }\end{array}$ & $\begin{array}{c}1167.29(28) \\
22,922\end{array}$ & $\begin{array}{c}697.87(27) \\
13,368\end{array}$ & $\begin{array}{l}555.36(27) \\
9,554\end{array}$ \\
\hline
\end{tabular}

Note: ${ }^{*}=$ significant at $10 \%,{ }^{* *}=$ significant at $5 \%$, and ${ }^{* * *}=$ significant at $1 \%$. 
union sector appears to afford protection to designated group employees against the higher layoff probability observed in the nonunion sector. There are two possible explanations for these findings: first, the assumption that designated group employees have less seniority than other employees may not be correct as well as the higher probability of a layoff in the nonunion sector is due to direct discrimination; and, second, the more "objective" seniority criterion may offer protection against such discrimination.

One of the most frequent statements about layoffs, at least in an employment equity context, is that they adversely affect members of the designated groups because, on average, such groups are likely to have less seniority than white able-bodied males. Moreover, such an adverse impact is hypothesized to constitute systemic discrimination. However, this assumption has been subjected to very few empirical tests. We addressed this limitation, and showed that members of the designated groups are more likely to be laid off than white able-bodied males. We conclude that this is support for the theory that designated group employees are adversely affected by layoffs, and by implication it constitutes systemic discrimination.

One frequent accusation is that unions and the seniority rule constitute significant barriers to the application of employment equity. Our results show that the probability of a layoff for members of the designated groups was lower among unionized employees. Therefore, we reject the notion that unions and the seniority rule are responsible for the adverse impact of layoffs on members of the designated groups. Furthermore, we propose that union membership is associated with a general degree of protection from layoffs, and this protection applies to both members of the designated groups and white able-bodied males.

We are particularly concerned that layoffs have an adverse impact on designated group because the issue can effectively be addressed by public policy. The negative social consequences of layoffs ${ }^{4}$ have resulted in the search for alternatives to short-term unemployment. ${ }^{5}$ According to Vrooman (1990), worksharing is a widely accepted alternative to layoffs

4. In addition to the potential for layoffs to adversely affect designated groups, there are many other negative social consequences: (1) it is a source of economic depravation, leading to anomia, psychic withdrawal, and political alienation (Aiken, Ferman, and Sheppard 1969); (2) for unions, layoffs lead to a lack of solidarity among union members during periods of layoffs (Shostak 1969); and (3) layoffs have negative psychological consequences for "survivors of layoffs" (Armstrong-Stassen 1994; Brockner et al. 1994).

5. Among the alternatives to layoffs are: (1) training redundant workers (Allen et al. 1978); (2) promoting inter-plant transfers (Bradburn 1964); and (3) restructuring compensation to remunerate high risk layoff groups (Foegen 1978). 
in Western European countries. Although worksharing plans vary by jurisdiction, they all involve reducing the number of hours for all employees and keeping the number of employees constant in response to a reduction in demand (Fallon and Weiler 1984). In this way, the burden of the decline is shared equally by all of the employees.

In summary, not only is the adverse impact of layoffs on members of the designated groups a form of systemic discrimination, but also a barrier for the achievement of equality and the promotion of progressive workplace practices to encourage workplace diversity. This is unfortunate because we believe that the equal treatment of all members of the workforce is ethically responsible, can create a sense of "fairness", which in turn can have a positive impact on performance and competitiveness.

\section{REFERENCES}

ADELL, B. 1982. "Restrictions on Management Rights to Lay Off." Workforce Reduction in Undertakings. E. Yemen, ed. Geneva: International Labour Office.

Aiken, M., L. FERMAn, and H. SHEPPARD. 1969. Economic Failure, Alienation and Extremism. Ann Arbour: The University of Michigan Press.

Allen, C., D. Mayall, J. Mitchell, and D. RoberTS. 1978. Layoff Time Training: A Key to Upgrading Workforce Utilization and ECCOC Affirmative Action: A Case Study in the Northern California Canning Industry. Washington: A Report Prepared for the Employment and Training Administration of the U.S. Department of Labor.

ARMSTRONG-STASSEN, M. 1994. "Coping with Transition: A Study of Layoff Survivors." Journal of Organizational Behavior, Vol. 15, No. 7, 597-621.

BEATTY, D. 1983. "Ideology, Politics, and Unionism." Studies in Labour Law. K. Swan and K. Swinton, eds. Toronto: Butterworths.

BEST, F. 1988. Reducing Workweeks to Prevent Layoffs: The Economic and Social Impact of Unemployment Insurance-Supported Worksharing. Philadelphia: Temple University Press.

BRADBURN, N. 1964. Inter-Plant Transfer: The Sioux City Experience. Chicago: University of Chicago National Opinion Research Centre.

BROCKNER, J., M. KONOVSKY, R. COOPER-SCHNEIDER, and R. FOLGER. 1994. "Interactive Effects of Procedural Justice and Outcome Negativity on Victims and Survivors of Job Loss." Academy of Management Journal, Vol. 37, No. 2, 397-409.

BRODY, D. 1993. "Workplace Contractualism." Industrial Democracy in America. N. Lichtenstein and H. Harris, eds. New York: The Cambridge University Press. 
CoRNFiELD, D. 1983. "Chances of Layoff in a Corporation: A Case Study." Administrative Science Quarterly, Vol. 28, No. 1, 503-520.

CORNFIELD, D. 1987. "Ethnic Inequality in Layoff Chances: The Impact of Unionization on Layoff Procedure." Redundancy, Layoffs and Plant Closures: Their Character, Causes and Consequences. R. Lee, ed. London: Croom Helm.

DULUDE, L. 1995. Seniority and Employment Equity for Women. Kingston: IRC Press.

FALLON, R. and P. WEILER. 1984. "Firefighters v. Stotts: Conflicting Models of Racial Justice." Supreme Court Review, Vol. 1, No. 1, 29-45.

FISCHER, B. 1976. "Seniority is Healthy." Labor Law Journal, August, 497503.

FOEGEN, J. 1978. "Interruptible Service: Not Only for Utilities." Human Resources Management, Vol. 17, No. 1, 26-28.

GRAVES, F. and T. DUGAS. 1993. "Program Evaluation Report, Worksharing Evaluation, Technical Report." Ottawa: Employment and Immigration Canada.

LAPP, J. 1946. How to Handle the Problem of Seniority. New York: National Foremen's Institute.

MEDOFF, J. 1979. "Layoffs and Alternatives Under Trade Unions in U.S. Manufacturing." American Economic Review, Vol. 69, No. 3, 380-395.

MONTGOMERY, M. 1991. "New Evidence on Unions and Layoff Rates." Industrial and Labor Relations Review, Vol. 44, No. 4, 708-721.

REID, F. 1982. "UI-Assisted Worksharing as an Alternative to Layoffs: The Canadian Experience." Industrial and Labor Relations Review, Vol. 35, No. 3, 319-330.

REID, F. 1996. "Working Less and Enjoying It More." Family Security in Insecure Times. David Ross, ed. Ottawa: National Forum on Family Security, 24-48.

SHostaK, A. 1969. Blue Collar Life. New York: Random House.

U.S. COMmISSION ON CIVIL RIGHTS. 1977. Last Hired, First Fired: Layoffs and Civil Rights. Washington: U.S. Commission on Civil Rights.

VROOMAN, W. 1990. "An Essay on Short-Time Compensation." UI Research Exchange, Unemployment Insurance Occasional Paper 92-4, Employment and Training Administration, U.S. Department of Labor.

WEISS, A. 1990. Efficiency Wages: Models of Unemployment, Layoffs, and Wage Dispersion. Princeton: Princeton University Press.

Yemen, E. 1982. Workforce Reduction in Undertaking. Geneva: International Labour Office. 


\section{RÉSUMÉ}

\section{Les mises à pied basées sur l'ancienneté sont-elles discriminatoires?}

Le principe du "dernier entré - premier sorti " dans l'allocation des mises à pied est devenu une pratique courante de la gestion des ressources humaines tant en milieu syndiqué que non syndiqué. Ce principe est une source de sécurité d'emploi pour les travailleurs et, à sa face même, il est perçu juste par les employeurs, les employés et les syndicats. Mais un tel système de mise à pied peut aussi être une source de discrimination systémique contre les membres de groupes désignés (les femmes, les minorités visibles, les handicapés et les autochtones), ceux-ci ayant, en toute probabilité, passé moins de temps sur le marché du travail. Il devient alors très important d'examiner empiriquement la relation entre la décision de mise à pied et le statut des groupes désignés. Nous poursuivons ici deux objectifs: d'abord déterminer si les mises à pied affectent les groupes désignés de façon disproportionnelle et, ensuite, évaluer l'ancienneté sur tout impact négatif. À notre connaissance, c'est ici la première étude directe et systématique qui utilise des données nationales pour examiner les impacts négatifs de l'ancienneté sur des groupes désignés.

Nous basons notre théorie sur les hypothèses suivantes: d'abord, les employés faisant partie des groupes désignés sont probablement, en moyenne, moins anciens que les hommes blancs en bonne santé. Ensuite, les femmes ont, en toute probabilité, moins d'ancienneté que les hommes, parce que leur carrière est susceptible d'avoir été interrompue par la grossesse et l'éducation des enfants. De plus, nous faisons l'hypothèse que les minorités visibles ont probablement passé moins de temps dans la population active que les blancs car il est fort probable que plusieurs soient des immigrants récents au Canada. En outre, les personnes handicapées ont plus de chances que les autres à avoir interrompu leur lien avec le marché du travail en raison d'une participation à des programmes spéciaux de formation ou en raison de causes médicales. Finalement, les autochtones sont plus sujets à mise à pied vu leur temps de service plus court et vu leur attachement sporadique au marché du travail. Nous faisons également l'hypothèse que bon nombre d'employeurs utilisent l'ancienneté comme critère d'allocation des mises à pied et que ce principe de l'ancienneté trouve une application plus vigoureuse en milieu syndiqué, vu la fréquence des clauses d'ancienneté dans les conventions collectives. 
Les employés des groupes désignés seraient donc plus sujets aux mises à pied que les hommes blancs en bonne santé. Le système de l'ancienneté pourrait aussi causer une discrimination systémique, surtout depuis l'existence de cette alternative aux mises à pied que constitue le travail partagé. Il se pourrait alors qu'il n'y ait pas de raisons d'affaires valables pour préférer le recours aux mises à pied. De plus, il se peut que les employés des groupes désignés soient victimes de discrimination directe si les employeurs, maîtres discrétionnaires de la décision de mise à pied, accordent préférence aux hommes blancs en bonne santé. En de telles circonstances, le travail partagé éliminerait la discrimination puisque de tels programmes traitent tous les employés d'un groupe de travail sur le même pied.

Les données pour notre recherche proviennent de l'étude de la population active 1990 de Statistique Canada. L'échantillon compte 22 922 travailleurs à temps complet, dont 9554 syndiqués et 13368 non syndiqués. Nous analysons ces données en un certain nombre d'étapes. D'abord, nous comparons les taux non ajustés de mises à pied des groupes désignés à ceux des hommes blancs en bonne santé. Ensuite, nous examinons, en contexte bivarié, l'impact de deux variables clefs: le statut syndical et un mélange d'industries. Nous procédons ensuite à une analyse de régression logistique multivariée pour contrôler l'impact de plusieurs caractéristiques portant sur les individus, les emplois et les employeurs. La dernière analyse inclut différentes estimations pour les groupes agrégés et désagrégés.

Les données agrégées non ajustées démontrent que le taux brut de mises à pied pour les membres des groupes désignés était en fait plus bas que celui des hommes blancs en bonne santé. Cependant, une simple analyse de standardisation révèle que cette différence reflétait surtout l'impact de l'industrie, les membres des groupes désignés étant employés de façon disproportionnelle dans ces industries ayant un taux de mises à pied en dessous de la moyenne. Notre analyse de régression révèle que les membres des groupes désignés connaissent au plus haut taux de mises à pied que celui des hommes blancs en bonne santé, après que nous ayons contrôlé bon nombre de facteurs. Les équations de régression séparées pour les secteurs syndiqués et non syndiqués, incluant des variables désagrégées de groupes désignés, démontrent que le haut taux de mises à pied des membres des groupes désignés résulte d'abord d'une haute probabilité de mise à pied des femmes dans le secteur non syndiqué. Dans le secteur syndiqué, il n'y a aucun impact significatif du statut de groupe désigné sur la probabilité de mise à pied.

Notre première conclusion est à l'effet qu'il y a un certain appui à l'hypothèse voulant que les membres des groupes désignés soient affec- 
tés de façon disproportionnelle par les mises à pied, bien que cela soit limité aux femmes dans le secteur non syndiqué. Notre seconde conclusion est qu'il y a très peu d'appui à l'hypothèse que le système de mise à pied basé sur l'ancienneté dans le secteur syndiqué soit responsable de discrimination systémique envers les membres des groupes désignés. En fait, l'emploi dans le secteur syndiqué semble protéger les employés des groupes désignés contre cette haute probabilité de mise à pied observée dans le secteur non syndiqué. Il y a ici deux explications possibles: premièrement, l'hypothèse à l'effet que les membres des groupes désignés soient moins anciens que les autres peut être incorrecte; deuxièmement, la plus haute probabilité de mise à pied dans le secteur non syndiqué peut être due à de la discrimination directe et le critère plus objectif de l'ancienneté omniprésent en milieu syndiqué peut offrir plus de protection contre une telle discrimination que dans le secteur non syndiqué.

\section{RESÚMEN}

Los despidos por antiguedad, son discriminatorios? El impacto negativo de ciertos despidos por grupos designados

Los objetivos de este documento son: primero, determinar si los despidos afectan de manera desproporcionada a los miembros de grupos que benefician de la protección a grupos marginados ; y, segundo, analizar el impacto de la antigüedad en estos despidos. Nuestra hipótesis es que la antigüedad es un criterio de importancia en los despidos y que, debido a que los miembros de grupos marginados tienden a tener menos antigüedad, son ellos los que absorben en proporción el mas alto porcentaje de los despidos. Si la hipótesis es verdad, entonces estos despidos representan una forma de discriminación hacia los trabajadores de grupos marginados. Estudios empíricos confirman que la probabilidad de despido es mas alta en el caso de los grupos marginados. El papel de la antigüedad en el despido por el otro lado, no se comprobó, ya que el estudio no encontró una relación directa entre el despido y la antigüedad, sin embargo si se encontró una tendencia mas pronunciada a considerar la antigüedad en compañías sindicalizadas que en aquellas que no lo estaban. La conclusión es que la integración sistemática de trabajadores provenientes de grupos marginados no puede que reducir la discriminación sistemática en contra de estos grupos que resulta en ciertos casos en despidos. 